\title{
Suitable Drilled Paddy Varieties and Sowing Windows for Drilled Paddy in Sub Mountain Zone of Pune District of Maharashtra
}

\author{
Ankita M. Giri, N. V. Kashid, J. D. Jadhav and K. M. Kamble* \\ Department of Agricultural Meteorology; College of Agriculture, Pune; Mahatma Phule \\ Krishi Vidyapeeth, Rahuri, Ahmednagar, Maharashtra, India \\ *Corresponding author
}

\section{A B S T R A C T}

\begin{tabular}{|l|}
\hline Ke y w or d s \\
Rice varieties, \\
Sowing windows, \\
Yield, Drilled \\
Paddy, Yield \\
attributes
\end{tabular}

Keywords

Rice varieties,

Yield, Drilled

Paddy, Yield

attributes

\section{Introduction}

Rice (Oryza sativa L.) is one of the most important staple food grain crops of the world, which constitute the principle food for 60 per cent of the world's population and 2/3rd of Indian population. Total area under rice in India is 45.05 million hectares with annual production of 103.27 million tonnes, though production is large, the per hectare yield is very poor i.e. 2.29 tonnes ha-1, as compared to other rice growing countries like Egypt (6.45 tonnes ha-1), USA (5.63 tonnes $\left.\mathrm{ha}^{-1}\right)$, Japan (4.73 tonnes ha $\left.{ }^{-1}\right)$ and China (4.74 tonnes $\mathrm{ha}^{-1}$ ) (Wailes and Chavez, 2012). India is the world's second largest rice producer and consumer next to China. In the NorthWestern Indo-Gangetic Plains (IGP), transplanted rice is predominantly cultivated. Transplanting requires at least $25 \mathrm{ha}-\mathrm{cm}$ of water for puddling operation, which creates a dense clay layer in the sub-soil to prevent seepage losses. The current practice of excessive exploitation of groundwater has led to a decline in the quality of natural resources i.e. land and water. 
Drilled paddy with reduced tillage is an efficient resource conservation technology that holds great promise in the Indo-Gangetic Plain because of the following advantages, Saving in water up to $25 \%$ in DSR, Saving in energy up to $27 \%$ of diesel as pumping energy is saved for field preparation, nursery raising, puddling and reduced frequency of applying irrigation water, Saving of 35 to 40 man days / ha, Enhanced fertilizer use efficiency due to the placement of fertilizer in the root zone, Early maturity of crops by 7-10 days helps in the timely sowing of succeeding crops (De Datta, 1986), Reduction in methane emissions and global warming potential, Little disturbance to soil structure, Enhanced system productivity.

In Pakistan, rice transplantation is usually performed by hired expensive labor, which is not specialized to maintain the required plant population to achieve higher productivity (Mann et al., 2007). To overcome this problem, direct seeding of rice seems only viable alternatives in rescuing farmers (Aslam et al., 2008). This technique reduces labour needs by more than $25 \%$ in term of working hours.

The input requirements and the investment in direct seeded rice are much lower than in transplanted rice (Sunil et al., 2002). Direct seeded rice, if managed properly, can yield as high as transplanted rice (Hayat et al., 2003; Ali et al., 2007).

In Maharashtra, rice is cultivated over an area of 15.13 lakh hectares and an annual production of about 28.43 lakh tonnes with a productivity of $1879 \mathrm{~kg}$ ha-1 (Anonymous, 2013). Delay in sowing results in reduction of plant height, productive tillers, filled grain panicle-1 and grain yield (Shah and Bhurer, 2005). These results are in line with those reported by Akbar et al., (2010), Padhi (1995) and Mahajan et al., (2009).

\section{Materials and Methods}

The field experiment was conducted during kharif, 2019 at Agricultural Research Station Farm, Vadgaon Maval, Tal. Maval, Dist. Pune to study Studies on the effect of sowing windows on different varieties of drilled paddy in relation to climate change.

The experiment was laid out in Split plot with twenty treatment combinations and three replications. The treatment comprising five sowing windows viz., SW $\mathrm{SW}_{1}: 22^{\text {nd }} \mathrm{MW}\left(28^{\text {th }}\right.$ May to $3^{\text {rd }}$ June), $\mathrm{SW}_{2}: 23^{\text {rd }} \mathrm{MW}$ (4 June to 10 June), $\mathrm{SW}_{3}$ : $24^{\text {th }}$ MW (11 June to 17 June), $\mathrm{SW}_{4}: 25^{\text {th }} \mathrm{MW}$ (18 June to 24 June), $\mathrm{SW}_{5}$ : $26^{\text {th }}$ MW (25 June to 1 July) as main plot treatment and four paddy varieties viz., $\mathrm{V}_{1}$ : VDN- 3-51-18 (Indrayani), $\mathrm{V}_{2}$ : VDN-99-29 (Phule Samruddhi), $\mathrm{V}_{3}$ : IET-13549 (Bhogawati), $\mathrm{V}_{4}$ : RDN-99-1 (Phule Radha) as sub plot treatment. The gross plot size was $3.60 \mathrm{~m} \times 3.60 \mathrm{~m}$ and net plot size was $3.00 \mathrm{~m}$ $\mathrm{x} 3.00 \mathrm{~m}$.

The field experiment was laid out in split plot design with three replications. There were sixty treatment combinations comprising of five sowing windows viz., $22^{\text {nd }}, 23^{\text {rd }}, 24^{\text {th }}, 25^{\text {th }}$ and $26^{\text {th }} \mathrm{MW}$ and four varieties viz., VDN-351-18 (Indrayani), VDN-99-29 (Phule Samruddhi), IET-13549 (Bhogawati) and RDN-99-1 (Phule Radha). The gross and net plot size were $3.60 \mathrm{~m} \mathrm{x} 3.60 \mathrm{~m}$ and $3.00 \mathrm{~m} \mathrm{x}$ $3.00 \mathrm{~m}$, respectively.

\section{Results and Discussion}

\section{Effect of sowing times windows}

The mean plant height was significantly influenced by different sowing window is presented in Table 1 The kharif paddy sown during $24^{\text {th }} \mathrm{MW}$ has recorded significantly highest plant height at harvest $(83.9 \mathrm{~cm})$ and it was at par with $25^{\text {th }} \mathrm{MW}(82.9 \mathrm{~cm}), 26^{\text {th }} \mathrm{MW}$ 
$(80.7 \mathrm{~cm})$ and $23^{\text {rd }} \mathrm{MW}(80.0 \mathrm{~cm})$ respectively and significantly superior over $22^{\text {nd }} \mathrm{MW}$ $(76.6 \mathrm{~cm})$ at harvest. The number of tillers plant $^{-1}$ was significantly influenced due to different sowing windows at harvest (Table 1). The sowing of drilled paddy at $24^{\text {th }} \mathrm{MW}$ recorded significantly higher number of tillers (23) over rest of the sowing windows.

The number of spikelets plant ${ }^{-1}$ of drilled paddy was influenced significantly due to different sowing windows. The number of spikelets plant ${ }^{-1}$ was maximum (22.1) when sown at $24^{\text {th }} \mathrm{MW}$ which was significantly superior over rest of the sowing windows $26^{\text {th }}$ MW (19.1), $23^{\text {rd }}$ MW (18.8), and $22^{\text {nd }} M W$ (17.2) except it was at par with sowing at $25^{\text {th }}$ MW (20.6). The length of spikelet of paddy was recorded highest when sown during $24^{\text {th }}$ MW $(23.2 \mathrm{~cm})$ which is at par with $25^{\text {th }}$ MW $(22.4 \mathrm{~cm})$ and $26^{\text {th }}$ MW $(22.2 \mathrm{~cm})$ which is superior over $23^{\text {rd }}$ MW $(20.5 \mathrm{~cm})$ and $22^{\text {nd }}$ MW $(19.5 \mathrm{~cm})$. Significantly, the lowest length of spikelet was observed in $22^{\text {nd }} \mathrm{MW}$ $(19.5 \mathrm{~cm})$. The test weight of paddy was not influenced significantly due to different sowing windows of paddy (Table.1). The significantly higher test weight was observed in sowing of paddy in $24^{\text {th }}$ MW (21.8 g) which was followed by sowing of paddy in $25^{\text {th }}$ MW $(21.0 \mathrm{~g})$. The number of grains plant $^{-1}$ and grain weight spikelet ${ }^{-1}$ was influenced significantly due to different sowing windows of drilled paddy (Table 1).

The sowing of drilled paddy at $24^{\text {th }} \mathrm{MW}$ recorded maximum number of grains plant ${ }^{-1}$ (283) and grain weight spikelet $^{-1}(6.11 \mathrm{~g})$ which was significantly superior and it was at par with $25^{\text {th }}$ and $26^{\text {th }}$ MW sowing windows. The grain yield of paddy was influenced significantly due to different sowing window (Table.1). The grain yield was maximum $\left(54.06 \mathrm{q} \mathrm{ha}^{-1}\right)$ when paddy was sown at $24^{\text {th }}$ MW. Which is at par with $25^{\text {th }}$ MW $(51.72 \mathrm{q}$ $\mathrm{ha}^{-1}$ ) and $26^{\text {th }} \mathrm{MW}\left(50.74 \mathrm{q} \mathrm{ha}^{-1}\right)$ and $23^{\text {rd }} \mathrm{MW}$ and $22^{\text {nd }}$ MW was produce lower grain yield $\left(47.84 \mathrm{q} \mathrm{ha}^{-1}\right)$ and $\left(45.54 \mathrm{q} \mathrm{ha}^{-1}\right)$, respectively. The mean straw yield $\left(\mathrm{q} \mathrm{ha}^{-1}\right)$ was maximum $\left(59.68 \mathrm{q} \mathrm{ha}^{-1}\right)$ at $24^{\text {th }} \mathrm{MW}$ which is at par with $25^{\text {th }} \mathrm{MW}\left(56.33 \mathrm{q} \mathrm{ha}^{-1}\right)$ and $26^{\text {th }} \mathrm{MW}(56.17 \mathrm{q}$ $\left.\mathrm{ha}^{-1}\right)$. The lowest mean straw yield was obtained in $23^{\text {rd }}$ MW (48.63q $\left.\mathrm{ha}^{-1}\right)$ respectively.

\section{Effect of varieties}

The mean plant height was significantly influenced up to harvesting due to different varieties which is presented in Table. 1 The significantly maximum plant height was observed with variety Phule Samruddhi during total growth period i.e. 15DAS $(25.3 \mathrm{~cm}), \quad 30 \mathrm{DAS} \quad(42.8 \mathrm{~cm}), \quad 45$ DAS $(56.6 \mathrm{~cm}), \quad 60$ DAS $(71.8 \mathrm{~cm}), \quad 75 \quad$ DAS $(87.8 \mathrm{~cm}), 90$ DAS $(88.5 \mathrm{~cm})$ and at harvest $(89.3 \mathrm{~cm})$ over rest of the varieties except it was at par with Indrayani at 75 DAS $(84.2 \mathrm{~cm}), 90 \mathrm{DAS}(84.9 \mathrm{~cm})$ and at harvest $(85.8 \mathrm{~cm})$. The mean maximum number of tillers plant ${ }^{-1}$ (24.0) was found with variety Phule Samruddhi which was significantly superior over rest of the paddy varieties. The number of spikelets plant ${ }^{-1}$ of drilled paddy was influenced significantly due to different varieties (Table 14). The variety Phule Samruddhi significantly produced higher numbers of spikelets plant ${ }^{-1}$ (22.9) while in case of Phule Radha variety significantly lower numbers of spikelets plant ${ }^{-1}$ (16.5). The spike length of paddy was significantly higher in Phule Samruddhi $(24.1 \mathrm{~cm})$ which was at par with Indrayani $(22.4 \mathrm{~cm})$ The variety Phule Radha recorded significantly lower length of spike $(19.1 \mathrm{~cm})$.

The test weight was differed significantly due to different paddy varieties. Phule Samruddhi recorded significantly higher test weight (22.5 g) and at par with Indrayani (21.0 g) and significantly superior over rest of the varieties (Table 1). 
Table.1 Growth and yield parameters of drilled Paddy as influenced by different sowing windows and varieties

\begin{tabular}{|c|c|c|c|c|c|c|c|c|c|}
\hline Treatment & $\begin{array}{l}\text { Mean } \\
\text { height of } \\
\text { paddy } \\
\text { (cm) }\end{array}$ & $\begin{array}{c}\text { Mean } \\
\text { numbers } \\
\text { of tillers } \\
\text { of paddy }\end{array}$ & $\begin{array}{l}\text { No. of } \\
\text { spikel } \\
\text { et per } \\
\text { plant }\end{array}$ & $\begin{array}{c}\text { Spike } \\
\text { length } \\
(\mathrm{Cm})\end{array}$ & $\begin{array}{c}\text { Test weight } \\
\text { (g) }\end{array}$ & $\begin{array}{c}\text { No. of } \\
\text { grains per } \\
\text { plant }\end{array}$ & $\begin{array}{c}\text { Wt of } \\
\text { grains per } \\
\text { spikelet (g) }\end{array}$ & $\begin{array}{c}\text { Grain } \\
\text { Yield } \\
\left(\mathbf{q} \mathbf{h a}^{-1}\right)\end{array}$ & $\begin{array}{l}\text { Straw } \\
\text { Yield }\end{array}$ \\
\hline \multicolumn{10}{|l|}{ A. Sowing times (Main): } \\
\hline$T_{1}: 22 M W(28$ May to 3 June) & 76.6 & 18 & 17.2 & 19.5 & 18.3 & 219 & 5.13 & 45.54 & 48.63 \\
\hline$T_{2}: 23 M W(4$ June to10 June) & 80.0 & 20 & 18.8 & 20.5 & 19.2 & 239 & 5.39 & 47.84 & 52.29 \\
\hline$T_{3}: 24 M W(11 J u n e$ to 17 June) & 83.9 & 23 & 22.1 & 23.2 & 21.8 & 283 & 6.11 & 54.06 & 59.68 \\
\hline $\mathrm{T}_{4}: 25 \mathrm{MW}(18 J u n e$ to 24 June) & 82.9 & 22 & 20.6 & 22.4 & 21.0 & 262 & 5.89 & 51.72 & 56.33 \\
\hline $\mathrm{T}_{5}: 26 \mathrm{MW}(25 J u n e$ to1 July) & 80.7 & 20 & 19.1 & 22.2 & 20.8 & 253 & 5.85 & 50.74 & 56.17 \\
\hline S.E. $\mathbf{m} \pm$ & 1.39 & 0.80 & 0.77 & 0.43 & 0.40 & 9.75 & 0.11 & 1.57 & 1.62 \\
\hline C.D. at $5 \%$ & 4.53 & 2.62 & 2.51 & 1.40 & 1.32 & 31.79 & 0.37 & 5.13 & 5.29 \\
\hline \multicolumn{10}{|l|}{ B. Varieties (Sub plot): } \\
\hline $\mathrm{V}_{1}:$ VDN-3-51-18 (Indrayani) & 85.8 & 22 & 21.0 & 22.4 & 21.0 & 269 & 5.89 & 53.52 & 58.88 \\
\hline $\mathrm{V}_{2}:$ VDN-99-29 (Phule Samruddhi) & 89.3 & 24 & 22.9 & 24.1 & 22.5 & 295 & 6.33 & 58.51 & 64.59 \\
\hline $\mathrm{V}_{3}:$ IET-13549 (Bhogawati) & 77.0 & 19 & 17.8 & 20.7 & 19.4 & 229 & 5.44 & 45.65 & 49.54 \\
\hline V $_{4}:$ RDN-99-1 (Phule Radha) & 71.2 & 20 & 16.5 & 19.1 & 17.9 & 212 & 5.03 & 42.23 & 45.48 \\
\hline S.E. $\mathbf{m} \pm$ & 1.41 & 0.41 & 0.39 & 0.37 & 0.35 & 5.03 & 0.10 & 0.98 & 1.07 \\
\hline C.D. at $5 \%$ & 4.08 & 1.19 & 1.13 & 1.07 & 1.01 & 14.53 & 0.28 & 2.82 & 3.10 \\
\hline \multicolumn{10}{|l|}{ C. Interaction (A x B): } \\
\hline SE \pm betwwen levels of $A$ & 3.16 & 0.92 & 0.88 & 0.83 & 0.78 & 11.26 & 0.22 & 2.18 & 2.40 \\
\hline C.D at $5 \%$ & 9.11 & 2.65 & 2.53 & 2.40 & 2.25 & 32.50 & 0.63 & 6.31 & 6.93 \\
\hline SE+ between levels of $B$ & 0.94 & 0.57 & 0.56 & 0.49 & 0.48 & 1.99 & 0.25 & 0.84 & 0.87 \\
\hline C.D at $5 \%$ & 2.72 & 1.65 & 1.61 & 1.42 & 1.38 & 5.76 & 0.73 & 2.43 & 2.52 \\
\hline G.M & 80.8 & 20.4 & 19.6 & 21.6 & 20.2 & 251 & 5.67 & 49.98 & 54.62 \\
\hline C.V & 9.89 & 12.6 & 10.9 & 11.5 & 8.92 & 13.4 & 9.2 & 10.19 & 10.30 \\
\hline
\end{tabular}


The mean number of grains plant ${ }^{-1}$ and mean grain weight spikelet $^{-1}$ were significantly affected by different varieties. The mean number of grains plant ${ }^{-1}$ (295) and mean grain weight spikelet $^{-1}(6.33 \mathrm{~g})$ were found significantly higher in paddy variety Phule Samruddhi.

It was followed by Indrayani, Bhogawati and Phule Radha. The grain yield was significantly higher in Phule Samruddhi (58.51 $\mathrm{q} \mathrm{ha}^{-1}$ ) and significantly superior over rest of the paddy varieties.

The variety Phule Radha recorded significantly lower grain yield (42.23 $\left.\mathrm{q} \mathrm{ha}^{-1}\right)$. The mean straw yield $\left(\mathrm{q} \mathrm{ha}^{-1}\right)$ was higher in Phule Samruddhi (64.59 $\left.\mathrm{qha}^{-1}\right)$ which is at par with variety Indrayani $\left(58.88 \mathrm{qha}^{-1}\right)$ which is superior over Bhogawati (49.54q ha ${ }^{-1}$ ) and Phule Radha (45.48qha ${ }^{-1}$ ). The variety Phule Radha recorded significantly lower straw yield (45.48 q ha ${ }^{-1}$ ).

In conclusion the sowing of kharif paddy during $24^{\text {th }} \mathrm{MW}$ favourably influenced all the growth and yield components as compared to sowing of paddy during $23^{\text {rd }} \mathrm{MW}$, but it was at par with sowing of paddy during $25^{\text {th }} \mathrm{MW}$ and $26^{\text {th }} \mathrm{MW}$. It would be, therefore, advisable to sowing of Kharif paddy during $24^{\text {th }} \mathrm{MW}$ for obtaining the higher yield and it may extend upto $26^{\text {th }} \mathrm{MW}$ for obtaining the sustainable yield.

Among the four different varieties of paddy, VDN-99-29 (Phule Samruddhi) recorded significantly higher growth and yield components resulted in increased yield as compared to IET-13549 (Bhogawati) and RDN-99-1 (Phule Radha) but it was at par with VDN-3-51-18 (Indrayani). It would be, therefore, suggested to adopt VDN-99-29 (Phule Samruddhi) or VDN-3-51-18 (Indrayani) varieties for kharif paddy cultivation under sub mountain zone of Pune.

\section{Acknowledgement}

The authors are thankful to the Department of Agricultural Meteorology, College of Agriculture, Pune, for their support. This work would not have been possible without the support and guidance of Dr. J. D. Jadhav Head Department of Agril. meteorology College of Agriculture, Pune for their valuable insight and analysis.

Conflict of Interest: None declared

\section{References}

Akbar, N., Iqbal, A., Khan, H.N., Hanif., M.K., Basir, M.V. (2010). Effect of different sowing dates on the yield and yield component of direct seeded rice (Oryza sativa L.) J. Plant Breeding \& Crop Science. 2: 312-315.

Anonymous, (2013). IVth advance estimation of rice. Directorate of Agriculture, Government of Maharashtra, Pune.

Ali, R. I., T. H. Awan, Z. Manzoor, M. M. Ashraf, M. E. Safdar and M. Ahmad (2007). Screening of rice varieties suitable for direct seeding in Punjab. J. Anim. Pl. Sci. 17 (1-2): 24-26.

Aslam M., S. Hussain, M. Ramzan and M. Akhter (2008). Effect of different stand establishment techniques on rice yields and its attributes. J. Anim. Pl. Sci. 18 (2-3): 80-82

De datta, Pradeep K sharma, Surajit K, 1986. Physical properties and processes of puddled rice soils, Advances in soil Sciece, 139-178.

Hayat, K., I. U. Awan and G. Hassan (2003). Impact of seeding dates and varieties on weed infestation, yield and yield components of rice (Oryza sativa L.) under direct wet seeded culture. Pakistan J. Weed Sci. Res. 9: 59-65.

Mahajan, G., Bharaj, T.S. and Timsina, J. (2009). Yield and water productivity 
of rice as affected by time of transplanting in Punjab, India. Agricultural Water Management 96: 525-32.

Mann, R. A., S. Ahmad, G. Hassan and M. S. Baloch (2007). Weed management in direct seeded rice crop. Pakistan J. Weed Sci. Res. 13 (3-4): 219- 226.

Padhi, A.K. (1995). Response of rainfed rice to sowing times. Oryza. 32: 124-126.

Shah, M. L. and Bhurer, K. P. (2005). Response of wet seeded rice varieties to sowing dates. Nepal Agric. Res. J. 6: 35-38.

Sunil K., S. N. Khajanji, G. K. Shrivastava, R.
S. Tripathi and S. Kumar (2002). Comparative study of different methods of sowing on morphophysiological traits and economics of medium duration rice (Oryza sativa) inceptisols. J. Interacademicia 6 (2): 244-249. Yang S., Y. U. Sang, P. S. Tae and C. B

Wailes, E.J. and Chavez, E.C. (2012). International Rice Baseline with Deterministic and Stochastic Projections, 2012- 2021. World Rice Outlook pp. 16-42.

\section{How to cite this article:}

Ankita M. Giri, N. V. Kashid, J. D. Jadhav and Kamble, K. M. 2021. Suitable Drilled Paddy Varieties and Sowing Windows for Drilled Paddy in Sub Mountain Zone of Pune District of Maharashtra. Int.J.Curr.Microbiol.App.Sci. 10(01): 485-490.

doi: https://doi.org/10.20546/ijcmas.2021.1001.059 